\title{
Transient Receptor Potential Cation Channel Subfamily V Member 4
}

National Cancer Institute

\section{Source}

National Cancer Institute. Transient Receptor Potential Cation Channel Subfamily V

Member 4. NCI Thesaurus. Code C138115.

Transient receptor potential cation channel subfamily $\mathrm{V}$ member 4 ( $871 \mathrm{aa}, \sim 98 \mathrm{kDa}$ ) is encoded by the human TRPV4 gene. This protein plays a role in the modulation of calcium transport. 